\title{
Anti-corruption Institutions and Governmental Change in Pakistan
}

\section{Zulfiqar Ali}

\section{(2) OpenEdition}

\section{Journals}

Electronic version

URL: https://journals.openedition.org/samaj/4499

DOI: $10.4000 /$ samaj.4499

ISSN: $1960-6060$

\section{Publisher}

Association pour la recherche sur l'Asie du Sud (ARAS)

\section{Electronic reference}

Zulfiqar Ali, "Anti-corruption Institutions and Governmental Change in Pakistan", South Asia Multidisciplinary Academic Journal [Online], Free-Standing Articles, Online since 06 April 2018, connection on 21 September 2021. URL: http://journals.openedition.org/samaj/4499 ; DOI: https:// doi.org/10.4000/samaj.4499

\section{This text was automatically generated on 21 September 2021}

\section{c) $(1)$}

This work is licensed under a Creative Commons Attribution-NonCommercial-NoDerivatives 4.0 International License. 


\section{Anti-corruption Institutions and Governmental Change in Pakistan}

\section{Zulfiqar Ali}

The author dedicates this article to anonymous reviewer 1.

In much of the recent research in security studies, Pakistan has been viewed as a serious threat to the region and the world because of the risk posed by terrorist groups potentially gaining access to the country's nuclear explosives (Blair 2011, Clarke 2013). Comparative political studies portray full democracy as a cure for extremism (Brooks 2009), bad governance (Stockemer 2009) and corruption (Rock 2009). Yet in the case of Pakistan, many authors have considered the army an impediment to rather than a facilitator of the development of democracy (Shah 2014) and a supporter of Islamic extremism (Nasr 2004). Critics of the armed forces of Pakistan usually cite the country's beleaguered political history as evidence. Indeed, since independence in 1947, three military takeovers (1958-1971, 1977-1988, 1999-2008) have disrupted democratic governments. Since 2008, although the military has retreated to the barracks, commentators have pointed out that it retains an influential role in the political sphere (Shah and Asif 2015). Yet very few Pakistan scholars, including those having worked on corruption, such as Faisal Khan (2007) or Sumaira Samad (2008), have examined the association between the pursuit of accountability and the use of anti-corruption agencies for political purposes.

2 The relation between the practice of democracy and the activity of anti-corruption institutions, however, deserves attention. Several studies on democracy and democratization argue that democracy cannot impart political stability and establish civilian supremacy over the military unless it coincides with good governance and the rule of law (Kohn 1997, Nicolescu-Waggonner 2016). Among Asian countries, only Hong Kong and Singapore have been relatively successful in reducing corruption due to the political commitment of their leaders and the impartial implementation of anticorruption measures (Quah 2011). This fact highlights the role of political will as a key factor in the successful implementation of anti-corruption reforms. 
3 The paper focuses on some of Pakistan's key institutions of governance-anti-corruption agencies-in order to find out whether a change of government brings about certain policy changes within anti-corruption agencies in favor of governmental political parties. Indeed, some authors have exposed the political use of anti-corruption agencies such as the NAB (Chêne 2008, Khan, Kakakhel, and Dubnick 2004), but these studies only highlight specific instances. As a result, we have no full view of the overall performance of anticorruption agencies in connection with parties in government. This paper is the first focusing on performance data and trying to explain the overall performance from the political perspective.

Pakistan's first anti-corruption organization, ${ }^{1}$ the Ehtesab Cell (EC), was established by the November 1996 Ehtesab Ordinance promulgated by the caretaker government of Prime Minister Malik Meraj Khalid, and then operated under the elected government of Nawaz Sharif, who passed the Ehtesab Act, 1997. In November 1999, it was transformed by the National Accountability Ordinance into the National Accountability Bureau (NAB), after General Pervez Musharraf staged a military coup and proclaimed that his government would subject politicians and administrators to "ruthless" accountability (Musharraf 2006:150). After a decade during which elected governments were regularly dismissed on grounds of corruption, Pakistan and its anti-corruption agencies have been overseen by four distinct governments since 1999. First, the state came under direct military rule on October 12, 1999 when General Musharraf overthrew the elected government of Nawaz Sharif, initiating a period of "military regime." Second, a transition from direct to indirect military rule took place in October 2002 when the Pakistan Muslim League-Quaid-i-Azam (PML-Q), under the patronage of the army, emerged as the majority party in the general elections and ruled the country for the next five years. Third, Musharraf's loyalist party, the PML-Q, lost to its rival political parties in the February 2008 general elections, after a country-wide protest movement that contested Musharraf's rule in 2007. The Pakistan People's Party (PPP) managed to form a coalition government and rule the country for the following five years (2008-2013). Fourth, the PPP's tenure, tainted by allegations of misuse of power and mismanagement, contributed towards the overwhelming victory of the Pakistan Muslim League-Nawaz (PML-N) in the May 2013 general elections. As a result, the PML-N came to power and brought the accountability institutions under its control.

Relying on the NAB data combined ${ }^{2}$ with an analysis of anti-corruption laws-the Ehtesab Ordinance, 1996, the Ehtesab Act, 1997, and the National Accountability Ordinance, 1999 - , this article examines the entanglement of accountability procedures with the actual struggle over power, an entanglement so deep that it shapes both the constitution and the evolution of anti-corruption organizations. The first section of the article discusses the political factors that have played a crucial role in the formation of Pakistan's anticorruption organizations. The second section turns to the legal provisions underpinning accountability institutions and argues that the anti-corruption legal system tends to favor powerful individuals over weaker ones. The third section analyzes the actual performance of anti-corruption agencies to show that political considerations have largely influenced their conduct. Indeed, the paper suggests that the same institutions that have aggressively convicted corrupt officials under some governments have entered into plea discussions under others, a fact which highlights that government transitions have serious effects on the conduct of supposedly independent anti-corruption mechanisms. Indeed, Pakistan's anti-corruption institutions have largely been used by 
those in power to maintain their grip on the state by weakening their opponents. The army has used anti-corruption agencies to hold civilian politicians accountable, while the sitting government has used them against political parties in the opposition. Finally, the paper concludes that a high level of political animosity results in a high level of performance for accountability institutions.

\section{Undemocratic foundations}

When supposedly independent state institutions are used to serve the interests of the governing party, this process is called "politicization" of institutions (Pierre 2004:3). The politicization of state institutions takes place not only in recent states with hybrid regimes or defective democracies but also in old democracies with established rule-of-law traditions (Peters, Falk, and Pierre 2004). No state has thus developed truly independent institutions-institutions operating without any concern for the interests and concerns of the key members of the government (Collins 2011). Yet, some political systems are quite clearly far more politicized than others. In the case of Pakistan, several public administration scholars have accused the civil services of favoring those in power (Chaudry 2011, Khurshid 2011). The classical perspective on bureaucracy-an efficient machine marked by certain impersonal characteristics, one that is able, in Max Weber's words, to "treat everybody without regard to the person" (Weber, Roth and Wittich 1978:956) - has rarely been witnessed in operation in Pakistan (Wilder 2009)-or perhaps anywhere at all (Collins 2011).

7 A few examples will illustrate the degree of politicization in Pakistan. The highest judicial authority, the Supreme Court, has repeatedly endorsed military takeovers, in spite of clear constitutional provisions on civilian control of the military (State v. Dosso and another 1958; Begum Nusrat Bhutto v. Chief of Army staff and Federation of Pakistan 1977; Syed Zafar Ali Shah and others v. General Pervez Musharraf, Chief Executive of Pakistan and others 2000). This intertwined conduct of the judiciary and politics in Pakistan has been described as the "judicialization of politics" (Kausar 2013) or "politicization of judiciary" (Dawood 1994). Judges are often accused of granting political favors even when they apparently remain neutral in the proceedings (Newberg 2002:228). The bureaucracy, often slow in performing its duties, tends to become highly efficient when called on to provide services to dominant groups (Zafarullah and Akhter 2001). For instance, the administrative elite has rigged water management in various parts of the country in favor of powerful landlords, hence using water as a means to patronize political allies and harass opposition members (Mustafa 2002, Wegerich and Hussain 2016). This reminds us in some ways of Marx's analysis that the bureaucracy uses the state apparatus as its private property (Marx, O'Malley, and Davis 1994:14). The police administration is also subject to similar biases: while it effectively manages protocol and guarantees the security of the political elite, it has an inclination to become callous and disinterested when ordinary citizens are concerned (Petzschmann 2010). Another example is that of the revenue department, which frequently comes up with new tax amnesty schemes as an incentive for powerful people to voluntarily bring themselves within the tax net (Cheema 2012, Levi and Suddle 1989).

Such examples indicate that state institutions whose legitimacy depends in principle on delivering public goods and services, enforcing law and order, establishing the rule of law, and protecting the rights of individuals, have tended to serve those in power. Public 
administrators have usually been subservient to the political elite during civilian rule, expanding the latter's political base by intimidating political opponents and patronizing allies. Yet most administrators change their loyalties and defy their old masters when the military takes over through a coup (Mustafa 2002, Shafqat 1999, Tanwir and Fennell 2010). The flaws and shortcomings inherent in Pakistan's administrative system seem not to be the result of arbitrary factors but may have certain structural roots (Islam 1989, 2004). Anti-corruption institutions have been created within these fragile and polarized political and institutional settings in hopes they would apprehend any corrupt official without any bias. We may assume that democratic governments usually have an incentive to pursue anti-corruption efforts in fear of losing voters' support. But the association between democracy and corruption has demonstrated a somewhat unusual pattern in Pakistan, which comes to light when examining the particular conditions in which the country's anti-corruption institutions were established.

Indeed, neither the Ehtesab Cell nor the National Accountability Bureau was created by a democratic government. The first agency was established by an appointed caretaker government after the dismissal of the second Benazir Bhutto government in November 1996, a time marked by bitter inter-party rivalry between two major political parties-the PML-N and the PPP (Arif 2001, Rizvi 2000b). According to article 224 of the 1973 Constitution, the sole duty of the caretaker government is to oversee the general elections and the transfer of power to the newly elected government (CIRP 2015). Its mission being limited and of a strictly executive nature, it cannot in principle make significant policy decisions. However, in 1996, the unelected setup went beyond its mandate and established an accountability agency in spite of repeated criticisms coming from political parties, to which the caretaker Prime Minister, Malik Meraj Khalid, replied that accountability was far more important than elections (LaPorte 1997:122). The controversial formation of the EC by the caretaker administration reveals that the interest of unelected institutions played a key part in the creation of the EC.

When the PML-N won the 1997 general elections with an absolute majority and formed a government; it did not challenge the unconstitutional and undemocratic foundation of the EC. Instead, it used it to harass and intimidate members of the opposition. For example, the EC incriminated the former Prime Minister Benazir Bhutto on charges of misuse of power and possession of assets beyond known sources of income. Likewise, Nusrat Bhutto (mother of Benazir Bhutto and a member of the National Assembly) was also under suspicion of having accumulated assets beyond legal sources of income. Asif Ali Zardari (husband of Benazir Bhutto and an MNA) was detained on five corruption offences. As a result, party defection and horse-trading widened the rift between the government and opposition parties (Rizvi 1999:181). While the conflict with opposition parties worsened, the government developed serious disagreements with the army, which eventually led to a military takeover in October 1999 (Rizvi 2000a). The chairman of the EC was arrested on Musharraf's order on the charge of using the agency for party purposes (2006:133). The government and civil society challenged the legitimacy of the coup. However, the SC not only validated it, but also tasked the military government to make the political elite, bureaucrats and powerful private individuals truly accountable ( Syed Zafar Ali Shah and others v. General Pervez Musharraf, Chief Executive of Pakistan and others 2000). The verdict also expressed serious concern over the EC's role in harassing political opponents. 
11 Having received authorization from the ultimate judicial authority, nothing stood in the way of the army's will to prosecute the civilian elite. The military government adopted a new anti-corruption law-the National Accountability Ordinance-and replaced the EC with a more powerful anti-corruption agency-the National Accountability Bureau-on November 16, 1999 (Musharraf 2006:150). Among various changes, the Musharraf government introduced a provision to tackle the problem of defaulted bank loans. One of the major strategies of public corruption in Pakistan is the deliberate failure to repay bank loans, even when the obligor has the capacity and possesses sufficient assets to fulfill the legal contract. In many instances, politically powerful business groups, large landowners, and politicians manage to secure soft loans from banks and later have them written off. ${ }^{3}$ The Supreme Court of Pakistan (SC) took a suo motu action in January 2008an act that a court may perform on its own without receiving any formal application-on massive loan write-offs: loans worth more than Rs. 54 billion ( $\$ 516$ million) have been written off from 1991 to 2009 (Deadbeats got loans of 54 billion Written off loans v. Supreme Court of Pakistan 2007). Surprisingly, the provision of willful default was introduced by the same government that approved massive write-offs in October 2002.

Moreover, the NAB official record from October 1999 to December 2016 shows that more than 627 individuals have been charged with (deliberate) default, 300 of living beyond any known source of income, 700 of misusing public offices, 1,500 with corruption and corrupt practices, 50 of cheating the public at large, 50 with embezzlement and 1,800 for various corrupt practices. ${ }^{4}$ With the aim of bringing deliberate default under the jurisdiction of the anti-corruption organization, in October 1999, the Musharraf government added section 5(r) called "willful default" to the National Accountability Ordinance (NAO 1999). This change in the law was justified on the grounds it would act as a deterrent for politicians and private businessmen tempted to engage in corrupt practices. However, after the PML-Q came into power in October 2002, the then finance minister, Shaukat Aziz, introduced a scheme for writing off loans that around 50,000 people benefited from, including politicians and business men. When a confidential report on the scheme submitted to the National Assembly's Public Accounts Committee was leaked in 2007, the SC took action. However, no further progress has been made and the names of most beneficiaries remain unknown.

After Musharraf was ousted in 2008, none of the elected governments have attempted to dismantle the $\mathrm{NAB}$, despite the fact it was founded by a military government. More importantly, none tried to bring the military and the judiciary-the two powerful institutions that brought an end to civilian rule in 1999-under the NAB's jurisdiction. The controversial creation and the subsequent perpetuation of the EC and the NAB by elected governments reveal two essential features of the interdependence between conflictual politics and accountability. First, the EC and the NAB were established by nonelected institutions that had an interest in making elected representatives accountable. Second, the fact that the jurisdiction of the accountability organizations has not been extended to the military and the judiciary exposes the shortfalls of the democratic setup in Pakistan. Elected governments have been unwilling to replace the subservient organizations with strong autonomous ones. 


\section{Biased legal provisions}

14 foundation of accountability institutions in Pakistan but have also shaped the legal provisions underpinning anti-corruption institutions-the Ehtesab Ordinance, 1996, the Ehtesab Act, 1997, and the National Accountability Ordinance, 1999-in a manner such that these tend to favor dominant over weak individuals. point. When the PML-N came to power in February 1997, it did not challenge the undemocratic establishment of the EC. Instead, it went on to change certain sections of the law to its advantage, such as article 13. In the Ehtesab Ordinance, 1996, article 13 gave the right to the (indirectly elected) President of Pakistan to appoint the head of the EC after "consultation" with the Prime Minister, the leader of the opposition in the National Assembly, and the Chief Justice of Pakistan (Gazette of Pakistan 1996). The consultation procedure may seem to limit executive power, but in practice no office can invalidate the appointment made by the President of Pakistan.

The elected civilian government of Nawaz Sharif was uneasy with the appointing authority resting with the President, since the very same office was responsible for the dismissal of three previous elected governments, precisely on grounds of corruption. President Ghulam Ishaq Khan dismissed the governments of Benazir Bhutto in August 1990 and Nawaz Sharif in April 1993 and President Farooq Ahmed Laghari ousted Benazir Bhutto's government in November 1996. Predictably, the government of Nawaz Sharif came up in May 1997 with its own tailor-made law-the Ehtesab Act, 1997 (EA)-bringing the organization under its actual political control by changing the procedure to appoint the Chief Ehtesab Commissioner: the Federal Government after consultation with the leader of the opposition and the Chief Justice of Pakistan would now appoint the head of the EC (EA 1997).

However, while the government had been keen from the start to amend article 13 with regard to the appointing authority, it refused to strike down article 17 known as "voluntary return," which was arguably the most contentious part of the law. According to the "voluntary return" provision, all charges may be dropped and no further inquiry undertaken if an accused person voluntarily returns stolen money (EA 1997). Although article 17 was meant as an incentive for corrupt persons to return stolen money, this clause has also been used in furthering the interests of PML-N. In the shadow of harsh trial outcome, the voluntary return provision has been used as an incentive, and as a pressure tool to strike political deals with public officials.

Within a year of the adoption of the Ehtesab Act, the PML-N government felt compelled to amend the law. In February 1998, right after its candidate Rafiq Tarar was elected by the Parliament as the new President of Pakistan, the party in power tried to expand the jurisdiction of the EC and to vest greater power in its chief by promulgating the Ehtesab (Amendment) Ordinance, 1998 (Gazette of Pakistan 1998). The ordinance included several significant amendments to the Ehtesab Act, 1997. Firstly, it added two sections-29(a) and 29(b) - to the law that empowered the head of the EC to discharge any accused person from prosecution even after the charge was framed. Section $29(\mathrm{~b})$ declared absolute trust in the conduct of the head of the EC, which meant that the law presumed every action taken by the head of the agency to be actually done in good faith. No third party had 
rights to recover damages caused during his or her tenure as the head of the EC. The amendment allowed greater authority and legal protection to the head of the EC. More specifically, the head now had the power to release anyone from prosecution, a prerogative which could be used in exchange for switching political loyalties. The proposed amendment could thus facilitate political bargaining and negotiation. Secondly, the proposed amendment widened the jurisdiction of the organization by modifying the definition of a corrupt act. Article 3(d) of the Ehtesab Act, 1997 defined a corrupt act in terms of illegitimate benefits given away to a spouse or dependents. The 1998 amendment replaced the "spouse or dependents" with "any other person," thus enlarging the scope of the anti-corruption institution.

19 However, private corruption, as well as acts of corruption committed within military or judicial institutions, were deliberately left outside the jurisdiction of the anti-corruption organization. The Ehtesab Act, 1997 focused on bureaucratic and political corruption, that is, corruption within bureaucratic and elected political offices. Although the EC was tasked with "eradicat[ing] corruption and corrupt practices from public offices" (EA 1997), there was no provision in the law regarding any act of corruption committed by a private person, military personnel or judge. This exclusive focus on civilian and bureaucratic officials indicates a prejudice against political and civilian institutions.

When the NAB succeeded the EC in October 1999, the military regime also replaced the Ehtesab Act, 1997 with a new law-the National Accountability Ordinance. However, there remained biases similar to those inherent in the Ehtesab Act, 1997. For instance, article 15 of the NAO lays out different punishments for the same offence depending on whether it is committed by a public person or a private individual. If a public official is convicted on the basis of a plea bargain, s/he will be immediately discharged and disqualified from holding any public office for ten years. On the other hand, the law does not propose any sentence should a similar act be committed by a private person (NAO 1999). ${ }^{5}$

The office and powers of the chief of the anti-corruption institution were again contested. Under section 6(b)(i) of the NAO, the authority of the President to appoint the chairman of the NAB became subject to that of the self-proclaimed Chief Executive of Pakistan, General Pervez Musharraf, who was actually in control of the appointment process and its duration. Musharraf's NAO also conferred on the chairman of the NAB the power to make appointments within the organization, to frame rules and even to discharge an accused person without the approval of the court. Yet, ironically, such a powerful chairman, under the law, could be terminated by the President of Pakistan without any reason. Musharraf later argued that such a powerful chairman was necessary to "put the fear of God into the rich and powerful who had been looting the state" (Musharraf 2006:150).

Musharraf's accountability law was challenged in the SC in April 2001 to investigate what it called "excessive delegation of power" to the institutional chief (Khan Asfandyar Wali and others v. Federation of Pakistan through. Cabinet Division, Islamabad and others 2001). The highest court explained that the authority to appoint and dismiss the head of the NAB resting with a single person gave the President of Pakistan-who by then was none other than General Musharraf himself $f^{6}$-an unwarranted degree of control over the agency. The SC went on to declare that parts of the NAO subverted the doctrine of the separation of powers, according to which legislative, executive and judicial authorities should remain separate and limited in such a way that each office holds the others to account (Khan Asfandyar Wali and others v. Federation of Pakistan through. Cabinet Division, Islamabad and others 2001). The jury struck down parts of the law and recommended that the Chief 
Executive of Pakistan be required to consult with the Chief Justice of Pakistan for the future appointment of the Chairman, that the Chairman be appointed for a nonextendable period of four years, and that the Chairman be removed by the President if and only if the Supreme Judicial Council of Pakistan recommended his/her dismissal (Gazette of Pakistan 2001). ${ }^{7}$ Thus, instead of proposing an independent and performancebased mechanism for the appointment and removal of the head of the most important anti-corruption organization, the $\mathrm{SC}$ assigned itself a sort of political role in this process.

But President Musharraf had no intention of relinquishing his control over the NAB. When his political party, the PML-Q, came to power after the October 2002 general elections, the Chief Executive of Pakistan once again amended the law through ordinance to put aside the ambitious judiciary. According to the amendment, the chairman would now be appointed by the President in "consultation" with the leader of the house (Prime Minister) and the leader of the opposition in the National Assembly (Gazette of Pakistan 2002). Since the Prime Minister was handpicked under Musharraf's rule and installed as the de jure ruler, the accountability agency effectively came back under the control of the President. The leader of the opposition insisted that the word "consultation" should be understood as "approval," which would give the opposition leader a strong role in the appointment process. Interestingly, the court agreed with the opposition's definition of "consultation" in the hope that it would put an end to the misuse of the accountability agency to discriminate against rival political groups. ${ }^{8}$ The judgment read "for a consultation to be meaningful and purposive an attempt should be made to reach at some consensus" (Chaudhry Nisar Ali Khan v. Federation of Pakistan 2011).

Three points may be underlined here. First, the army, the executive and the judiciary all sought to extend their control over the anti-corruption organization-first the EC and then the NAB-which shows that none of them was willing to grant institutional autonomy to the anti-corruption mechanism. Second, the Ehtesab Ordinance, 1996, the Ehtesab Act, 1997 and the National Accountability Ordinance, 1999 favored strong institutions such as the military and judiciary over weaker ones like the bureaucratic and elected offices. Thus, anti-corruption laws target bureaucrats and politicians but ignore judicial and military officials.

\section{The politicized performance of the NAB}

The NAB's accountability process includes four stages. The NAB first receives a complaint or itself initiates an inquiry into an alleged act of corruption (inquiry stage). If a person under inquiry voluntarily comes forward and agrees to return the stolen amount, the NAB may enter into a settlement called "voluntary return." Voluntary return neither results in conviction or penalty nor requires any approval from a trial court. ${ }^{9}$ If the $N A B$ fails to get a defendant to agree to such a settlement, the NAB may either close the case or open a formal investigation (investigation stage). This is the second stage of the accountability process, where a defendant may enter into a settlement called "plea bargain," different from voluntary return in two respects. First, it results in conviction for a public office holder. Second, it requires a court's approval. If a defendant and the NAB fail to enter into a plea bargain, the NAB brings the case before a trial court (trial stage). At this third stage, the defendant may still enter into a plea agreement until the court reaches the final verdict. At the last stage, an accountability court tries the case, but the defendant has the right to appeal against the decision in a higher court. 
Let us now turn to the actual performance of the National Accountability Bureau in order to evaluate in what way governmental change impacts its activity. Table I below gives us an overview of the activities of the NAB under various governments.

Table I: Overview of the activities of the NAB under various governments

\begin{tabular}{|c|c|c|c|c|c|}
\hline Cases & $\begin{array}{l}\text { Military } \\
\text { Regime }\end{array}$ & $\begin{array}{l}\text { Indirect Military } \\
\text { Rule }\end{array}$ & $\begin{array}{l}\text { PPP } \\
\text { Government }\end{array}$ & $\begin{array}{l}\text { PML-N } \\
\text { Government }\end{array}$ & Total \\
\hline Cases filed & 599 & 1304 & 1895 & 1629 & 5427 \\
\hline Convictions & 192 & 186 & 75 & 7 & 460 \\
\hline $\begin{array}{l}\text { Voluntary } \\
\text { returns }\end{array}$ & 0 & 319 & 937 & 954 & 2210 \\
\hline Plea bargains & 57 & 213 & 330 & 332 & 932 \\
\hline Pending & 191 & 102 & 358 & 291 & 1153 \\
\hline -in court & 161 & 99 & 281 & 238 & 990 \\
\hline -with NAB & 30 & 3 & 77 & 53 & 163 \\
\hline Acquitted & 116 & 158 & 133 & 26 & 433 \\
\hline Withdrawn & 43 & 115 & 62 & 19 & 239 \\
\hline
\end{tabular}

Source: Author's calculation based on data available on the NAB official website (http:// www.nab.gov.pk/news_events.asp).

In principle, we may assume that when anti-corruption organizations achieve significant impartiality and attain credibility, they are more likely to resist political interference in their investigative activities and decision-making process, and vice versa. It seems appropriate to evaluate the performance of an anti-corruption organization under the assumption that if the transfer of power from one political party to another does not significantly affect the activities of the agency, then we may say that the organization has attained a certain degree of autonomy. However, if transition and succession in government-for example from a military regime to indirect military rule or from one democratic government to another- dramatically affects the activities of an anticorruption organization such that the conduct of the agency coincides with the interests of the governing party, then we may safely conclude that the organization is heavily politicized.

Studies have shown that the effectiveness of punishment in deterring offenders increases with the severity of the punishment (Moneymaker 1986:382). However, recent literature argues that the deterrent effect depends more on the perceived certainty of the sentence than on its severity (Nagin 2013). Therefore, in order to understand the functioning of the $\mathrm{NAB}$ and its effect as a deterrent on potential offenders, we need to apprehend the degree of certainty of the punishment it metes out. To that end, we shall examine the number of convictions for each regime type: the higher the conviction rate, the more certain the 
punishment for potential offenders. Thus, the number of convictions for each regime type offers a measure for assessing the effectiveness of an anti-corruption body under various governments.

\section{Convictions}

Given the fact that Pakistan's powerful political elite has deep ties with high-ranking officials in the bureaucracy, it may be safely assumed that members of the bureaucracy and elected individuals do not generally undermine one another's respective interests. Additionally, because the Chairman of the NAB is appointed through a political processby the leader of the house (Prime Minister) and the leader of the opposition in the National Assembly-, we may also safely assume that the Chairman shall be susceptible to external influences. Put simply, in times of good rapport between the party in government and opposition parties, we may expect that the NAB tends not to prosecute top-ranking officials. Moreover, lower-ranking officials are assumed to be less influential as they enjoy no ties either with powerful elected politicians or with officials in the bureaucracy. We will shortly see that yearly data on the conviction of top officials strongly support these hypotheses.

In order to understand the activity of the $\mathrm{NAB}$, it is necessary to examine the convicted officials' ranks. In Table II, public officials have been loosely classified into three distinct ranks-top, middle and low. The top rank notably includes the Prime Minister, cabinet ministers, and chief secretaries-administrative heads of state institutions and CEOs of private firms. The middle rank includes senior officers of police or officers equivalent to the rank of assistant director. Non-commissioned officers such as station officers, clerks, or managers have been treated as lower-ranking officials.

31 Table II shows the number and proportion of convictions within a particular rank for each regime-the yearly average is calculated by dividing total convictions within a particular rank by the amount of time each regime was in power. ${ }^{10}$ For example, the military regime ruled Pakistan for three years from October 1999 to October 2002, during which time the NAB secured 116 convictions of top-ranking officials. According to the calculation, under the military government, the NAB secured 38.6 convictions of topranking officials each year. Similar calculations have been made for voluntary returns, plea bargains, withdrawal, pending and acquitted.

Table II: Convictions

\begin{tabular}{|c|c|c|c|c|c|}
\hline \multirow{2}{*}{$\begin{array}{l}\text { Rank of officers } \\
\text { convicted }\end{array}$} & \multicolumn{4}{|c|}{ The NAB under: } & \multirow{2}{*}{$\begin{array}{l}\text { Total } \\
1999 \\
2016\end{array}$} \\
\hline & $\begin{array}{l}\text { Military } \\
\text { Regime }\end{array}$ & $\begin{array}{l}\text { Indirect } \\
\text { Military Rule }\end{array}$ & $\begin{array}{l}\text { PPP } \\
\text { Government }\end{array}$ & $\begin{array}{l}\text { PML-N } \\
\text { Government }\end{array}$ & \\
\hline Top-ranking & 116 & 47 & 17 & 1 & 181 \\
\hline Yearly average & 38.6 & 8.8 & 3.2 & 0.28 & \\
\hline Middle-ranking & 14 & 26 & 12 & 2 & 54 \\
\hline Yearly average & 4.6 & 4.9 & 2.2 & 0.6 & \\
\hline
\end{tabular}




\begin{tabular}{|l|l|l|l|l|l|}
\hline Low-ranking & 62 & 113 & 46 & 4 & 225 \\
\hline Yearly average & 20.6 & 21.2 & 8.8 & 1.1 & \\
\hline All ranks & 192 & 186 & 75 & 7 & 460 \\
\hline Yearly average & 64 & 34.9 & 14.3 & 2.0 & 26.1 \\
\hline
\end{tabular}

Source: Author's calculation based on data available on the NAB official website (http:// www.nab.gov.pk/news_events.asp).

Table II shows a stark contrast in the activity of the NAB between military and democratic periods. Put together, more than 82 percent of convictions within all ranks were obtained during direct (41.7 percent) and indirect military rule (40.4 percent). On the other hand, only 16.3 percent of total convictions took place under the PPP government and 1.9 percent under PML-N rule. On a yearly basis, an average of 64 convictions within all ranks took place under military rule, against 34.9 under indirect military rule, 14.3 during the PPP government and 1.9 during the PML-N government. The conviction rate of topranking officials under military governments wholly differs from that under Nawaz Sharif's government. Courts convicted 38.6 officials of higher ranks under the military regime on a yearly basis, whereas 27 officials of the same rank were sentenced when Nawaz Sharif was in power, i.e. only one person in almost four years. There were only 18 convictions of top-ranking officials during a total of eight years of civilian rule (20082016), while 116 officials were convicted during three years of the military regime (19992002). These numbers give the impression that the organization that worked from 1999 to 2008 was not the same as that working after 2008. A certain political climate, discussed below, helps explain why there is a dramatic variation in the number of convictions between military and democratic periods.

33 A deeper look into the data reveals similarly contrasted patterns between direct and indirect military rule. When Musharraf had no political party to support (1999-2002), the $\mathrm{NAB}$ reached the highest conviction rate in Pakistan's history. However, after Musharraf became the veiled and undeclared leader of the PML-Q, the number dropped even though the indirect military rule lasted for five years and four months: the NAB convicted only 47 higher-ranking office holders. The data indicates that the agency was relatively aggressive in pursuing top-ranking officials during military rule, but comparatively less so once the military decided to have a political face with the PML-Q. We may surmise that Musharraf deemed a strong and uncompromising attitude towards corruption unlikely to get him support from splinter groups breaking away from the PML-N.

Regarding public officials of top and middle ranks, Table II shows that they have also been convicted more under direct and indirect military rule (1999-2008) than under civilian governments (2008-2016). Additionally, from one civilian government (2008-2013) to another (2013-2016), the yearly conviction rate progressively declined. However, lowerranking officials-the least influential group-have been convicted more often under democratic governments. We will also see below (in sub-sections "voluntary returns" and "plea bargains") that the same group has entered into settlements more than top- and middle-ranking officials when the NAB operated under civilian governments. The focus on lower-ranking officials benefits the $\mathrm{NAB}$ and civilian governments in a very important way. Since the NAB publishes yearly performance data without showing the rank of the 
accused official, relatively improved performance in prosecuting lower-ranking officials shows improvement in the overall performance of the agency. In addition, it hides weaknesses and gaps in charging and prosecuting top-ranking officials.

The radical discrepancy in the number of convictions from one government to another suggests that a change at the helm seriously affects the activity of the NAB. These statistics bolster the idea that the political and administrative system in Pakistan relies largely on patronage networks whereby the political elite in collusion with high-ranking bureaucracy officials share and protect each other's interests (Lyon 2002). Perhaps, this is why the Federal Investigation Agency established in 1975 has yet to convict a single public official of the rank of assistant director or above (Hafiez 2002:48). Before the establishment of the EC and the NAB, the Federal Investigation Agency was responsible for investigating the offences of bribery and misuse of public office.

\section{Voluntary returns}

As for the number of convictions, there are great discrepancies in the number of voluntary returns registered by the NAB under various governments. However, these show a reversed pattern. On a yearly basis, an average 215 voluntary returns within all ranks have been registered during the PML-N government, 149 under PPP rule, 50 under indirect military rule and not a single case of voluntary return was reported during the entire military regime. Significantly, more than 85 percent of total voluntary returns were reported under the two civilian governments (2008-2013 and 2013-2016): 43.1 percent under the PPP government and 42.4 under the PML-N government. These figures indicate that the $\mathrm{NAB}$ under civilian governments focused more on voluntary settlements than on convictions. By contrast, not a single voluntary return was reported during direct military rule, and the NAB only began working on voluntary returns after the PML-Q came to power in 2002.

Table III: Voluntary returns

\begin{tabular}{|c|c|c|c|c|c|}
\hline \multirow{2}{*}{$\begin{array}{l}\text { Rank of officers } \\
\text { convicted }\end{array}$} & \multicolumn{4}{|c|}{ The NAB under: } & \multirow{2}{*}{\begin{tabular}{|l} 
Total \\
1999 \\
2016
\end{tabular}} \\
\hline & $\begin{array}{l}\text { Military } \\
\text { Regime }\end{array}$ & $\begin{array}{l}\text { Indirect } \\
\text { Military Rule }\end{array}$ & $\begin{array}{l}\text { PPP } \\
\text { Government }\end{array}$ & $\begin{array}{l}\text { PML-N } \\
\text { Government }\end{array}$ & \\
\hline Top-ranking & 0 & 3 & 27 & 18 & 48 \\
\hline Yearly average & 0.0 & 0.6 & 5.1 & 5.0 & \\
\hline Middle-ranking & 0 & 47 & 123 & 165 & 335 \\
\hline Yearly average & 0.0 & 8.8 & 23.4 & 46.0 & \\
\hline Low-ranking & 0 & 269 & 787 & 771 & 1827 \\
\hline Yearly average & 0.0 & 50.5 & 149.9 & 215.4 & \\
\hline All ranks & 0 & 319 & 937 & 954 & 2210 \\
\hline
\end{tabular}




\begin{tabular}{|l|l|l|l|l|l|}
\hline Yearly average & 0.0 & 59.8 & 178.5 & 266.5 & \\
\hline
\end{tabular}

Source: Author's calculation based on data available on the NAB official website (http:// www.nab.gov.pk/news_events.asp). only 6.3 percent (or a yearly average of 0.6) during indirect military rule. An
extraordinarily high percentage of voluntary returns from high-ranking officials during The breakdown according to officials' ranks shows a similar pattern. During the PPP
government, more than 56 percent of the returns (or a yearly average of 5.1, more or less
maintained by the following PML-N government) came from top-ranking officials, against the PPP government shows that the civilian administration was not much interested in convicting powerful officials but preferred receiving misappropriated funds. Conversely, during the PML-Q government under indirect military rule, the NAB adopted a policy of not accepting the offers of voluntary return, as indicated by their relatively low percentage. For low-ranking officers, the agency approved about 50 voluntary return applications per year (269 in total) during the military regime, but this number jumped to almost 150 per year (787 in total) when the PPP was in power, a trend even intensified under the PML-N, with a yearly average of about 215 returns from low-ranking officials (for a total of 771 over less than four years). The returns from middle-ranking officials progressively increased as the agency came under growing oversight by democratic governments.

The number of voluntary returns needs to be compared with the conviction rate and the total number of cases. For instance, during the PML-N government, approximately 85 percent of total investigations undertaken by the NAB targeted low- and middle-ranking officials, and about 71.3 percent of total cases were disposed of as voluntary settlements. As a result of this policy, the number of convictions dipped to the record low of seven cases over less than four years, representing 1.5 percent of total convictions over the sixteen-year period.

\section{Plea bargains}

According to section 25(b) of the NAO known as "plea bargaining," if an accused person agrees to return the illicit money after the commencement of the investigation or a jury trial, the defendant may enter into a plea bargain, subject to court approval (NAO 1999). As in the case of convictions and voluntary returns, the number of plea bargains suggests that the transfer of power from the military regime to the civilian government or between civilian governments has affected the activity of the NAB, particularly in the manner in which it helped those in power carry out their political goals and further their interests.

The yearly average of plea bargains across all ranks progressively increased over the years: an average of 19 plea bargains were settled every year under the military government, around 40 under indirect military rule, 62 under the PPP government and 92 during PML-N rule. Most of the plea bargains were approved under the two democratic governments (71 percent); against only 29 percent under direct and indirect military rule. These figures again indicate that the NAB under Musharraf was not as keen on bargaining with offenders as later civilian governments. 
Nearly 50 percent of total plea settlements under the PML-N government were concluded with top-ranking officials, while this percentage stood at less than 15 percent under the PPP government. In the PPP period, however, almost 45 percent of total plea bargains were concluded with low-ranking officials, against 25.4 percent in the PML-N period. Therefore, the NAB under the PML-N government focused on plea bargaining with topranking officials rather than with the middle- or low-cadre officials, whereas the NAB under the PPP government followed the opposite policy. This result bolsters the public perception that the PPP government was relatively more tolerant towards corruption than the PML-N government. ${ }^{11}$

Table IV: Plea bargains

\begin{tabular}{|l|l|l|l|l|l|}
\hline \multirow{2}{*}{$\begin{array}{l}\text { Rank of officers } \\
\text { convicted }\end{array}$} & \multicolumn{4}{|l|}{ The NAB under: } \\
\cline { 2 - 6 } & $\begin{array}{l}\text { Military } \\
\text { Regime }\end{array}$ & $\begin{array}{l}\text { Indirect } \\
\text { Military Rule }\end{array}$ & $\begin{array}{l}\text { PPP } \\
\text { Government }\end{array}$ & $\begin{array}{l}\text { PML-N } \\
\text { Government }\end{array}$ & $\begin{array}{l}\text { Total } \\
\mathbf{2 0 1 6}\end{array}$ \\
\hline Top-ranking & 40 & 20 & 25 & 83 & 168 \\
\hline Yearly average & 13.3 & 3.7 & 4.7 & 23.1 & \\
\hline Middle-ranking & 8 & 118 & 180 & 178 & 484 \\
\hline Yearly average & 2.6 & 22.1 & 34.2 & 49.7 & 280 \\
\hline Low-ranking & 9 & 75 & 125 & 71 & \\
\hline Yearly average & 3.0 & 14.0 & 23.8 & 19.8 & 932 \\
\hline All ranks & 5 & 213 & 330 & 332 & 92.7 \\
\hline Yearly average & 19.0 & 39.9 & 62.8 & & \\
\hline
\end{tabular}

Source: Author's calculation based on data available on the NAB official website (http:// www.nab.gov.pk/news_events.asp).

\section{Pending, acquitted and withdrawn cases}

The fact that the NAB was affected by the transition from military to civilian rule is also visible by critically assessing the data relating to cases which were withdrawn, challenged in appellate courts, acquitted, or remain pending. In particular, the anti-corruption organization under civilian governments failed to bring 76 percent of cases involving high-ranking officials before a trial court (see Table V). Conversely, the same agency has been very efficient in expediting cases involving low-ranking officials, with only 0.3 percent of cases still pending in the NAB. These percentages suggest that, under democratic governments, the $\mathrm{NAB}$ has been reluctant to bring high-ranking officials before trial courts, and as a result a large number of cases have remained pending in the agency. However, the organization was efficient in bringing low-ranking officials to court. Under direct or indirect military rule, about 78 percent of indicted top-ranking officials were acquitted and/or their case withdrawn. As suggested by these and other 
percentages, the NAB under Pervez Musharraf either convicted or acquitted high-ranking officials. In other words, the agency remained relatively reluctant to offer settlements to top-ranking officials.

Table V: Pending, acquitted and withdrawn

\begin{tabular}{|c|c|c|c|c|c|c|}
\hline \multirow{2}{*}{$\begin{array}{l}\text { Rank } \\
\text { accused }\end{array}$} & \multirow{2}{*}{ of officers } & \multicolumn{4}{|c|}{ The NAB under: } & \multirow{2}{*}{ Total } \\
\hline & & $\begin{array}{l}\text { Military } \\
\text { Regime }\end{array}$ & $\begin{array}{l}\text { Indirect } \\
\text { Military Rule }\end{array}$ & $\begin{array}{l}\text { PPP } \\
\text { Government }\end{array}$ & $\begin{array}{l}\text { PML-N } \\
\text { Government }\end{array}$ & \\
\hline \multirow{8}{*}{$\begin{array}{l}\text { Top- } \\
\text { ranking }\end{array}$} & $\begin{array}{l}\text { Pending in } \\
\text { Court }\end{array}$ & 119 & 98 & 87 & 72 & 376 \\
\hline & $\begin{array}{l}\text { Yearly } \\
\text { Average }\end{array}$ & 39.6 & 18.3 & 16.5 & 20.1 & \\
\hline & Acquitted & 79 & 55 & 32 & 5 & 171 \\
\hline & $\begin{array}{l}\text { Yearly } \\
\text { Average }\end{array}$ & 26.3 & 10.3 & 6.0 & 1.3 & \\
\hline & Withdrawn & 30 & 46 & 17 & 5 & 98 \\
\hline & $\begin{array}{l}\text { Yearly } \\
\text { Average }\end{array}$ & 10.0 & 8.6 & 3.2 & 1.3 & \\
\hline & $\begin{array}{l}\text { Pending in } \\
\mathrm{NAB}\end{array}$ & 24 & 2 & 48 & 35 & 109 \\
\hline & $\begin{array}{l}\text { Yearly } \\
\text { Average }\end{array}$ & 8.0 & 0.3 & 9.1 & 9.7 & \\
\hline \multirow{7}{*}{$\begin{array}{l}\text { Middle- } \\
\text { ranking }\end{array}$} & $\begin{array}{l}\text { Pending in } \\
\text { Court }\end{array}$ & 19 & 60 & 64 & 90 & 233 \\
\hline & $\begin{array}{l}\text { Yearly } \\
\text { Average }\end{array}$ & 6.3 & 11.2 & 12.1 & 25.1 & \\
\hline & Acquitted & 18 & 23 & 40 & 7 & 88 \\
\hline & $\begin{array}{l}\text { Yearly } \\
\text { Average }\end{array}$ & 6.0 & 4.3 & 7.6 & 1.9 & \\
\hline & Withdrawn & 7 & 29 & 26 & 4 & 66 \\
\hline & $\begin{array}{l}\text { Yearly } \\
\text { Average }\end{array}$ & 2.3 & 5.4 & 4.9 & 1.1 & \\
\hline & $\begin{array}{l}\text { Pending in } \\
\mathrm{NAB}\end{array}$ & 6 & 1 & 27 & 18 & 52 \\
\hline
\end{tabular}




\begin{tabular}{|c|c|c|c|c|c|c|}
\hline & $\begin{array}{l}\text { Yearly } \\
\text { Average }\end{array}$ & 2.0 & 0.18 & 5.14 & 5.0 & \\
\hline \multirow{10}{*}{$\begin{array}{l}\text { Low- } \\
\text { ranking }\end{array}$} & $\begin{array}{l}\text { Pending in } \\
\text { Court }\end{array}$ & 23 & 152 & 130 & 76 & 381 \\
\hline & $\begin{array}{l}\text { Yearly } \\
\text { Average }\end{array}$ & 7.6 & 28.5 & 24.7 & 21.2 & \\
\hline & Acquitted & 19 & 80 & 61 & 14 & 174 \\
\hline & $\begin{array}{l}\text { Yearly } \\
\text { Average }\end{array}$ & 6.3 & 15.0 & 11.6 & 3.9 & \\
\hline & Withdrawn & 6 & 40 & 19 & 10 & 75 \\
\hline & $\begin{array}{l}\text { Yearly } \\
\text { Average }\end{array}$ & 2.0 & 7.5 & 3.6 & 2.7 & \\
\hline & $\begin{array}{l}\text { Pending in } \\
\mathrm{NAB}\end{array}$ & 0 & 0 & 2 & 0 & 2 \\
\hline & $\begin{array}{l}\text { Yearly } \\
\text { Average }\end{array}$ & 0.0 & 0.0 & 0.3 & 0.0 & \\
\hline & All ranks & 350 & 586 & 553 & 336 & 1825 \\
\hline & $\begin{array}{l}\text { Yearly } \\
\text { average }\end{array}$ & 116.6 & 109.9 & 105.3 & 93.8 & \\
\hline
\end{tabular}

Source: Author's calculation based on data available on the NAB official website (http:// www.nab.gov.pk/news_events.asp).

\section{Political interests and the NAB}

Radical shifts in the conduct of the NAB have occurred as transfers of power took place. We may therefore wonder what drove such contrasting shifts.

For example, under direct military rule the agency focused on convicting top-ranking officials, while there was not a single case of voluntary returns and very few plea bargains. This was a period of high tension between political players, and Musharraf was then casting himself as a savior liberating the country from corrupt politicians. Although the NAB reached its highest level of convictions under direct military rule, the number of convictions and indictments of top-ranking officials greatly dropped after the PML-Q came into power. The NAB began to accept a greater number of voluntary returns and plea bargains, and now they were largely focused on middle- and low-ranking officials. This approach in part improved the recovery of stolen funds; however it decreased conviction rates. When enmity between political parties cooled, the activity of the NAB either ebbed or occurred in non-significant areas involving low- and middle-ranking officials. 

and political compromise, the NAB emphasized settlements over convictions. The hostility that had been a stand-out characteristic of Pakistan's political system in the preceding years somewhat dissipated during the PPP government, as a sort of political understanding between the government and the opposition helped the PPP government complete its five-year term. This era was marked by a low degree of inter-political rivalry and institutional antagonism but tainted by a very large number of allegations of corruption. The good rapport between the PPP and PML-N is likely to have limited the activities of the NAB. Instead of prosecuting and convicting corrupt officials, the NAB entered into negotiations with accused individuals. As a result, it recorded the highest number of voluntary returns and plea bargains, as the understanding between the government and the opposition paved the way for the $\mathrm{NAB}$ and the accused to reach settlements. Moreover, almost 87 percent of the cases investigated by the institution during the PPP government indicted low and middle-ranking officials, public officers that entailed no serious political consequences for the government. This policy certainly helped the PPP complete its tenure.

\section{Conclusion}

No democratic government has created an anti-corruption body in Pakistan. ${ }^{12}$ The main institutions-the $\mathrm{EC}$ and the $\mathrm{NAB}$-were established in the wake of the overthrow of democratically-elected governments by non-elected actors. The highest courts have validated the legitimacy of these organizations while later democratically-elected governments have continued to run them. The illiberal origin of anti-corruption organizations in Pakistan exposes the latent conflict between elected and non-elected groups as they attempt to use anti-corruption agencies for their own benefit. While the NAB's existence is not contested as such, various institutions still attempt to exert control over the anti-corruption organization, as illustrated by the conflicts surrounding the chairman's appointment and role or the actual implications of the term "consultation." In fact, neither the military nor the government nor the judiciary has ever earnestly intended to grant full autonomy to the accountability organization. Each office has sought to bring the operation of the organization into line with its own version of accountability and institutional interests.

As a result of its undemocratic foundations, the anti-corruption organization is regulated by laws that are negatively biased against public officials. The EC deliberately excluded harmful behavior in the private sector, the military and judiciary from its own jurisdiction, but focused instead on public malpractices. Although the NAO has taken a step towards bringing private-sector corruption under its jurisdiction, corrupt practices in the military and judiciary still fall outside of its legal authority. In addition, the NAO prescribes different punishments for the same offence committed by a public person or a private individual. It shows that sentences are intimately connected with the nature of one's employment. Punishment and its severity are embroiled with divided politics. Therefore, only weak institutions, groups and individuals are subject to accountability mechanisms.

Because it lacks independence from powerful institutions, the NAB is deeply affected by governmental change, as indicated by our data. The uneven performance of the NAB shown by the dataset demonstrates that the institution has failed to free itself from the

South Asia Multidisciplinary Academic Journal , Free-Standing Articles 
influences of government political parties and that its conduct has been intimately tied to a conflict-prone political climate. As soon as the degree of political inclusiveness increases, the anti-corruption mechanism tends to fall back on low- and middle-rank officials and is most likely to capitalize more on voluntary returns and plea bargains, resulting in a low conviction rate. The various shifts in the activity of the NAB suggest a political use of the institution. In particular, we observe that in the recent past elected governments have tended to favor voluntary returns and plea-settlements over convictions, in spite of numerous allegations of corruption, and have targeted low- and middle-ranking officials rather than top-ranking ones. This strategy has served to maintain a good rapport between the PPP and the PML-N, thus ensuring the low degree of inter-political rivalry and institutional antagonism that allowed the PPP-led government to be the first in Pakistan's history to complete its five-year mandate. Although this was rightly celebrated as a significant democratic achievement, the apparent stability of elected political institutions came at the cost of limiting the activities of the NAB and letting corrupt officials off the hook.

\section{BIBLIOGRAPHY}

Arif, Khalid Mahmud. 2001. Khaki Shadows: Pakistan 1947-1997. New York: Oxford University Press. Begum Nusrat Bhutto v. Chief of Army staff and Federation of Pakistan (1977).

Blair, Charles P. 2011. "Fatwas for Fission: Assessing the Terrorist Threat to Pakistan's Nuclear Assets." Bulletin of the Atomic Scientists 67(6):19-33.

Brooks, Risa. 2009. "Researching Democracy and Terrorism: How Political Access Affects Militant Activity." Security Studies 18(4):756-88.

Chaudry, A. 2011. Political Administrators: The Story of the Civil Service of Pakistan. Oxford: Oxford University Press.

Chaudhry Nisar Ali Khan v. Federation of Pakistan (2011).

Cheema, Umar. 2012. Representation without Taxation!: An Analysis of Mps' Income Tax Returns for 2011 . Islamabad: Center for Peace and Development Initiatives and Center for Investigative Reporting in Pakistan.

Chêne, Marie. 2008. “Overview of Corruption in Pakistan.” Transparency International.

CIRP. 2015. The Constitution of the Islamic Republic of Pakistan. Lahore: Federal Law House.

Clarke, Michael. 2013. "Pakistan and Nuclear Terrorism: How Real Is the Threat?" Comparative Strategy 32(2):98-114.

Collins, Richard. 2011. "Modernist-Positivism and the Problem of Institutional Autonomy in International Law." Pp. 22-47 in International Organisations and the Idea of Autonomy: Institutional Independence in the International Legal Order, edited by R. Collins and N. D. White. London: Routledge. 
Dawood, Jan Mohammad. 1994. The Role of Superior Judiciary in the Politics of Pakistan. Lahore: Royal Book Co.

Deadbeats got loans of 54 billion Written off loans v. Supreme Court of Pakistan (2007).

EA, 1997. 1997. "Ehtesab Act, 1997" ACT No. IX OF 1997, Karachi: The Manager of Publications. Retrieved November 13, 2016 (http://www.na.gov.pk/uploads/documents/1324604966_239.pdf). Gazette of Pakistan, Extraordinary. 1996. The Ehtesab Ordinance, 1996, edited by M. o. J. a. P. A. Government of Pakistan. Islamabad: Printing Corporation of Pakistan.

Gazette of Pakistan, Extraordinary. 1998. Ehtesab (Amendment) Ordinance, 1998, edited by M. o. J. a. P. A. Government of Pakistan. Islamabad: Printing Corporation of Pakistan.

Gazette of Pakistan, Extraordinary. 2001. National Accountability (Amendment) Ordinance, 2001, edited by M. o. J. a. P. A. Government of Pakistan. Islamabad: Printing Corporation of Pakistan. Gazette of Pakistan, Extraordinary. 2002. National Accountability (Amendment) Ordinance, 2002, edited by M. o. J. a. P. A. Government of Pakistan. Islamabad: Printing Corporation of Pakistan. Hafiez, Munir. 2002. National Anti-Corruption Strategy. Islamabad: Printing Corporation of Pakistan. Islam, Nasir. 1989. “Colonial Legacy, Administrative Reform and Politics: Pakistan 1947-1987.” Public Administration and Development 9(3):271-85.

Islam, Nasir. 2004. "Sifarish, Sycophants, Power and Collectivism: Administrative Culture in Pakistan.” International Review of Administrative Sciences 70(2):311-30.

Kausar, Tasneem. 2013. "Judicialization of Politics and Governance in Pakistan: Constitutional and Political Challenges and the Role of the Chaudhry Court." Pp. 28-45 in Pakistan's Stability Paradox: Domestic, Regional and International Dimensions, edited by A. Misra, and M. E. Clarke. London: Taylor \& Francis.

Khan Asfandyar Wali and others v. Federation of Pakistan through. Cabinet Division, Islamabad and others (2001).

Khan, Faisal. 2007. "Corruption and the Decline of the State in Pakistan." Asian Journal of Political Science 15(2):219-47.

Khan, Masood, Niaz A. Kakakhel, and Mel Dubnick. 2004. "Prosecuting Corruption: The Case of Pakistan.” Pp. 26-27 in Ethics Forum, American Society for Public Administration.

Khurshid, Kiran. 2011. A Treatise on the Civil Service of Pakistan: The Structural-Functional History, 1601-2011. Lahore: Sang-e-Meel Publications.

Kohn, Richard H. 1997. “How Democracies Control the Military.” Journal of Democracy 8(4):140-53.

LaPorte, Robert. 1997. "Pakistan in 1996: Starting over Again.” Asian Survey 37(2):118-25.

Levi, M. and M. Suddle. 1989. "White-Collar Crime, Shamelessness, and Disintegration: The Control of Tax Evasion in Pakistan.” Journal of Law and Society 16(4):489-505.

Lyon, Stephen M. 2002. Power and Patronage in Pakistan. PhD, Social Anthropology, University of Kent, Canterbury.

Marx, K., J.J. O’Malley, and R.A. Davis. 1994. Marx: Early Political Writings. Cambridge: Cambridge University Press.

Moneymaker, James M. 1986. “The Infliction of Punishment: A Deterrent or Hydra?” Deviant Behavior 7(4):371-84.

Musharraf, Pervez. 2006. In the Line of Fire: A Memoir. London: Simon and Schuster. 
Mustafa, Daanish. 2002. “Theory Versus Practice: The Bureaucratic Ethos of Water Resource Management and Administration in Pakistan." Contemporary South Asia 11(1):39-56.

Nagin, Daniel S. 2013. "Deterrence in the Twenty-First Century." Crime and Justice 42(1):199-263. doi: $10.1086 / 670398$.

NAO. 1999. "National Accountability Ordinance." Islamabad: National Accountability Bureau. Retrieved June 10, 2015 (http://www.nab.gov.pk/Downloads/nao.asp).

Nasr, Vali. 2004. "Military Rule, Islamism and Democracy in Pakistan.” Middle East Journal 58 (2):195-209.

Newberg, Paula R. 2002. Judging the State: Courts and Constitutional Politics in Pakistan. Cambridge: Cambridge University Press.

Nicolescu-Waggonner, Cristina. 2016. No Rule of Law, No Democracy: Conflicts of Interest, Corruption, and Elections as Democratic Deficits. New York: State University of New York Press.

Peters, B. Guy, Maurice Falk, and Jon Pierre. 2004. The Politicization of the Civil Service in Comparative Perspective: A Quest for Control. London: Taylor \& Francis.

Petzschmann, Paul. 2010. Pakistan's Police between Centralization and Devolution. Oslo: Norwegian Institute of International Affairs.

Peters, B. Guy, and Jon Pierre. 2004. "Politicization of the Civil Services: Concepts and Causes." Pp. 1-13 in The Politicization of the Civil Service in Comparative Perspective: A Quest for Control, edited by B. G. Peters and J. Pierre. London: Taylor \& Francis.

Quah, Jon S.T. 2011. Curbing Corruption in Asian Countries: An Impossible Dream? Bingley: Emerald Group.

Rizvi, Hasan Askari. 1999. "Pakistan in 1998: The Polity under Pressure.” Asian Survey 39(1):17784.

Rizvi, Hasan Askari. 2000a. “Pakistan in 1999: Back to Square One.” Asian Survey 40(1):208-18.

Rizvi, Hasan Askari. 2000b. The Military and Politics in Pakistan, 1947-1997. Sang-E-Meel Publication. Rock, Michael T. 2009. “Corruption and Democracy." Journal of Development Studies 45(1):55-75.

Samad, Sumaira. 2008. "Combating Corruption: The Case of the National Accountability Bureau, Pakistan." Journal of Administration and Governance 3(1):90-100.

Shafqat, Saeed. 1999. "Pakistani Bureaucracy: Crisis of Governance and Prospects of Reform." The Pakistan Development Review 38(4):995-1017.

Shah, Aqil. 2014. "Constraining Consolidation: Military Politics and Democracy in Pakistan (20072013)." Democratization 21(6):1007-33.

Shah, Aqil, and Bushra Asif. 2015. "Pakistan in 2014: Democracy under the Military's Shadow." Asian Survey 55(1):48-59.

State v. Dosso and another (1958).

Stockemer, Daniel. 2009. "Does Democracy Lead to Good Governance? The Question Applied to Africa and Latin America." Global Change, Peace and Security 21(2):241-55.

Syed Zafar Ali Shah and others v. General Pervez Musharraf, Chief Executive of Pakistan and others (2000).

Tanwir, Maryam, and Shailaja Fennell. 2010. "Pakistani Bureaucracy and Political Neutrality: A Mutually Exclusive Phenomenon?” The Pakistan Development Review:239-59. 
Weber, Max, Günther Roth, and Claus Wittich. 1978. Economy and Society: An Outline of Interpretive Sociology. Berkeley: University of California Press.

Wegerich, Kai, and Asghar Hussain. 2016. "Creating Accountability: Representation and Responsiveness of the Irrigation Bureaucracy in Punjab, Pakistan.” Water International:1-20.

Wilder, Andrew. 2009. “The Politics of Civil Service Reform in Pakistan.” Journal of International Affairs 63(1):19.

Zafarullah, Habib, and Muhammad Yeahia Akhter. 2001. "Military Rule, Civilianisation and Electoral Corruption: Pakistan and Bangladesh in Perspective.” Asian Studies Review 25.

\section{NOTES}

1. Before the establishment of the Ehtesab Cell which was later succeeded by the National Accountability Bureau in November 1999, the Federal Investigation Agency (FIA), founded in January, 1975, was primarily responsible for investigating offences of bribery and abuse of public office. In 2004, the Government of Pakistan made the NAB solely responsible for anti-corruption operations. The FIA now investigates cases related to organized crime, smuggling, human trafficking, counterfeit currency, immigration and drugs.

2. Since its inception in November 1999, the NAB regularly updates performance data on its official website: http://www.nab.gov.pk/news_events.asp. What is used here is the approximately 16 years of available data (from October 1999 to December 2016). Despite the critical importance of governance and the rule of law for fragile democracies such as Pakistan, the statistical literature on Pakistan's anti-corruption institutions is almost non-existent.

3. For example, Fauzia Gilani, the wife of the then Prime Minister Yousuf Raza Gilani, got a writeoff worth Rs. 38 million $(\$ 342,000)$ in 2010.

4. Data is available at http://www.nab.gov.pk/news_events.asp.

5. In 2005, the jurisdiction of the NAB was challenged in the SC regarding the NAB's power to arrest or charge a private person-a person not holding public office and who has not aided or assisted or acted in collusion with a public office holder in accumulating illegal assets. The SC rejected the plea that the NAB only has jurisdiction over public officials. For details, see http:// www.supremecourt.gov.pk/web/user_files/File/Crl.A.140of2005.pdf.

6. General Pervez Musharraf forced Muhammad Rafiq Tarar to resign and took over as President of Pakistan on June 20, 2001.

7. The Supreme Judicial Council consists of five members: the Chief Justice of Pakistan, the two next most senior judges of the Supreme Court and the two most senior Chief Justices of High Courts.

8. See the constitutional petition "Against the appointment of Chairman, National Accountability Bureau."

9. The voluntary return provision was first introduced by the interim government through the Ehtesab Ordinance, 1996. Despite its controversial nature, the same provision made its way into the Ehtesab Act, 1997 and then into the National Accountability Ordinance, 1999.

10. The total number of convictions within a particular rank under one regime divided by the total time the regime lasted. Calculations are based on the following time periods: military regime, three years (October 1999 to October 2002); indirect military rule, five years and four months (October 2002 to February 2008); PPP Government, five years and three months (February 2008 to May 2013); PML-N Government, three years and seven months (May 2013 to December 2016). 
11. Several surveys are available including Transparency International, World Bank and IMF showing that the PML-N government performed better in combating corruption than the PPP government. For details on the Corruption Perception Index, see https://www.transparency.org/ country/PAK. For details on transparency, accountability, and corruption in the public sector published by the World Bank, see https://data.worldbank.org/indicator/IQ.CPA.TRAN.XQ? locations=PK.

12. Although the FIA came into existence during the elected government of Zulfiqar Ali Bhutto (1973-77), it was not created from scratch. Pakistan inherited from the British government a crime agency known as the "Federally Controlled Police Establishment," renamed "Pakistan Special Police Establishment" at the time of independence. However, in view of the increasing abuse of public office, Zulfiqar Ali Bhutto's government decided to tackle corruption. For this purpose, the jurisdiction of the Pakistan Special Police Establishment was expanded and renamed as FIA in 1975.

\section{ABSTRACTS}

In Pakistan, the struggle over power often provokes people to spin the law towards their own interests and (mis)use state institutions to reach political ends. Under such conflictual circumstances, anti-corruption institutions are frequently used by the people in power to persecute opposition parties. This paper has two aims. First, it attempts to show that political disputes and the conflict between civilian and military authorities have not only led to the foundation of anti-corruption agencies at the national level-the Ehtesab Cell (EC) and National Accountability Bureau (NAB)-but also created a bias against civilian institutions in the legal provisions that regulate their activity. Second, the paper uses new statistical data to show that the NAB, founded in November 1999, has tended to side with the interests of the parties and people in government.

INDEX

Keywords: Pakistan, corruption, politicization, inter-party conflict, civil-military relations

\section{AUTHOR}

\section{ZULFIQAR ALI}

Department of Philosophy, University of Karachi, Karachi, Sindh, Pakistan 